Send your letters to the Editor,

British Dental Journal

64 Wimpole Street

London

W1G 8YS

Email bdj@bda.org

Priority will be given to letters less than 500 words long.

Authors must sign the letter, which

may be edited for reasons of space.

\section{FUNDAMENTAL TRAINING}

Sir, in the third edition of The first five years the General Dental Council stipulates that newly qualified UK trained dentists should be competent at extraction of teeth, removal of roots and undertaking minor soft tissue surgery. ${ }^{1}$ We wished to determine whether recently qualified dentists felt properly prepared to perform such procedures, so an email questionnaire was circulated to $150 \mathrm{UK}$ vocational trainees via the postgraduate dental dean or local vocation training coordinator. Trainees were asked to rate their confidence in five key aspects of oral surgery: raising of a mucoperiosteal flap; use of elevators; bone removal; sectioning of teeth and intraoral suturing. ${ }^{2}$ Trainees were asked to rate their confidence with regard to each procedure as either: 'very confident'; 'confident'; 'not confident' or 'not done before'. Sixty-eight trainees responded to the questionnaire (45\%) (see Table 1). Fifty percent of trainees felt they were not confident at intraoral suturing and 17\% felt they were not confident using elevators, but there were no trainees who had not done these procedures before. Forty-two percent of trainees felt they were not confident at raising mucoperiosteal flaps and a further $9 \%$ had no previous experience. Thirty-two percent of trainees were not confident with bone removal and a further 25\% had no previous experience. Thirty-three percent of trainees felt they were not confident to section roots and a further $25 \%$ had no previous experience.

These procedures are all integral components of surgical tooth removal. The results presented suggest that UK dental graduates do not currently feel they meet the criteria set out in The first five years. The pattern of referrals to our department supports this suggestion. As a consequence of this lack of confidence in minor oral surgery, it will be difficult for many vocational or foundation trainees to achieve the more ambitious aims set out for competence in oral surgery in the Curriculum for Dental Foundation Programme Training. ${ }^{3}$

We believe that there is a need for further fundamental training in minor oral surgery, either within the undergraduate curriculum or within dental vocational/ foundation training. This should target specifically the trainee's ability to perform surgical tooth removal.

$$
\begin{array}{r}
\text { S. Patel, F. Evans, A. McKechnie } \\
\text { By email }
\end{array}
$$

1. General Dental Council. The first five years (interim). 3rd ed. London: GDC, 2008.

2. General Dental Council. The first five years. 2 nd ed. London: GDC, 2002

3. Committee of Postgraduate Dental Deans and Directors. A Curriculum for UK Dental Foundation Programme Training. 2007.

\begin{tabular}{|c|c|c|c|c|}
\hline & Not done & Not confident & Confident & Very confident \\
\hline Intraoral suturing & 0 & 50 & 50 & 0 \\
\hline Use of elevators & 0 & 17 & 50 & 33 \\
\hline Raising flap & 9 & 42 & 37 & 12 \\
\hline Bone removal & 25 & 32 & 26 & 17 \\
\hline Division of tooth & 25 & 33 & 33 & 9 \\
\hline
\end{tabular}

DOI: 10.1038/sj.bdj.2009.611

\section{NSD FROM IMPLANTS}

Sir, I would like to thank Kawaja and Renton (BDJ 2009; 206: 365-370) for their suggestion of a practical protocol to manage neurosensory disturbance (NSD) arising from the placement of dental intraosseous implants in the mandible. I certainly agree with their suggestion that implants are to be removed as soon as possible when NSD happens, though some authors suggest otherwise. ${ }^{1,2}$ I guess a dental practitioner will be lost for words in a court of law if the judge asks why the implant is not removed soon after NSD develops.

Whilst on this topic, may I suggest that practitioners adopt the local anaesthetic technique used by Heller and Shankland, ${ }^{2}$ whereby multiple local infiltrations are given instead of a usual standard inferior alveolar nerve block? Heller has placed over 8,000 mandibular implants using this approach without having any failure of achieving adequate anaesthesia. This approach allows a dental practitioner to be alerted sooner if the inferior alveolar canal and nerve is breached.

Lastly, a cautionary note for those who are dependent on dentopantomograms to view the mental foramen (ie nerve) for the planning of implant placement. A study at our centre found that non-visibility of the foramen is significantly increased in patients aged 50 or more. Hence, panoramic radiographs may not be sufficient for presurgical implant planning in older patients and may need to be supplemented with a CT or CBCT scan.

\section{W. C. Ngeow,} Kuala Lumpur

1. Bartling $R$, Freeman $K$, Kraut $R$ A. The incidence of altered sensation of the mental nerve after mandibular implant placement J Oral Maxillofac Surg 1999; 57: 1408-1412. 
2. Heller A A, Shankland W E II. Alternative to the inferior alveolar nerve block anesthesia when placing mandibular dental implants posterior to the mental foramen. J Oral Implanto/ 2001; 27: 127-133

DOI: 10.1038/sj.bdj.2009.612

\section{STABLE POSITIONS}

Sir, it is clear from the letter of C. H. Griffiths (BDJ 2009; 206: 448-449) just how strongly he feels let down following his dual qualification as a hygienist and therapist. His history of having moved from England following redundancies and then experiencing such difficulties in obtaining employment in Scotland have clearly been traumatic for him.

He is undoubtedly correct in considering that the NHS contract in England has resulted in the inability of general dental practices to expand NHS treatment provision as they would have liked. There are other factors affecting recruitment of therapists. Research in Scotland, ${ }^{1}$ England $^{2}$ and Wales $^{3}$ has shown that there is a considerable lack of awareness among general dental practitioners of the extent of the range of duties that a therapist can perform. My own experience as the head of a school which trains dental hygienists/therapists has shown that many GDPs are also unsure how the employment of a such a person will be viewed by their colleagues, acceptability by patients and how they will contribute financially to the practice. Where I work we are fortunate to have a number of dentists who find that working with therapists is effective, efficient and provides them with a different work pattern to that to which they had become accustomed.

The recent employment experience of hygienists/therapists in the North West of England is very different from that of Mr Griffiths. Each year newly qualified hygienists/therapists from the Greater Manchester School for Dental Care Professionals find it slightly easier to find suitable employment as therapists as the awareness of GDPs increases, although there is still limited opportunity. Employment as hygienists within NHS and private practices is easily obtained - indeed demand exceeds supply and I am frequently contacted by dentists who wish to employ a hygienist. A recent survey undertaken by Professor Robin
Davies of Manchester University for NHS North West has shown that the great majority of graduates of the three local schools work in the NHS as hygienists and therapists, and that their employment expectations have been met.

I feel very sorry for Mr Griffiths as he is now so disillusioned that he has decided to throw in the towel. However, his experience does not seem to be typical. I think that his tale indicates the importance of stable supportive positions and adds to the case for vocational training for hygienists/therapists. Is it ironic that there is an advert for two full-time salaried posts as therapists in Scotland and six posts in general dental practice for hygienists in England (albeit part-time) in the edition in which his letter is published?

\section{Wanless \\ Head of Greater Manchester School for Dental Care Professionals}

1. Ross M K, Ibbetson R J, Turner S. The acceptability of dually qualified dental hygienist-therapists to general dental practitioners in South-East Scotland. Br Dent J 2007; 202: E8.

2. Gallagher J L, Wright D A. General dental practitioners' knowledge of and attitudes towards the employment of dental therapists in genera practice. Br Dent J 2003; 193: 37-41.

3. Jones G, Devalia R, Hunter L. Attitudes of general dental practitioners in Wales towards employing dental hygienist-therapists. Br Dent J 2007; 203: E19.

DOI: 10.1038/sj.bdj.2009.613

\section{OSTENSIBLY ERRONEOUS}

Sir, I found the editorial in the recentmost issue of the $B D J^{1}$ rather intriguing. The notion that an universal theory does not exist to explain orthodontic tooth movement might be somewhat deficient. The pressure-tension theory was promulgated by Oppenhiem ${ }^{2}$ as first proposed by Sandstedt. ${ }^{3}$ This unsophisticated notion was substantially challenged by Moss $^{4}$ (following van der Klaauw $^{5}$ ) who described the Functional Matrix Hypothesis. ${ }^{6-9}$ More recently, Singh $^{10}$ described the Spatial Matrix Hypothesis, ${ }^{11}$ which was presented at the 11th International Facial Orthotropics Symposium in Tokyo, Japan, in November, 2007. If I'm not mistaken, the Spatial Matrix Hypothesis ${ }^{10,11}$ first proposed that gene-environmental interactions are associated with the formation of malocclusion. ${ }^{12}$ Thus, growth mechanisms and not growth outcome are inherited. Therefore, the notion that '... the body of the mandible, the length of which is under tight genetic control...' is ostensibly erroneous. For example, many data have shown that adults who wear a mandibular advancement device for the amelioration of obstructive sleep apnoea show a tendency for renewed mandibular growth, sometimes resulting in a Class III malocclusion and skeletal relationship. It is also too simplistic to say that 'families sharing the same diet, environment and genes are likely to be affected in the same way'. For example, in genetically-identical mice, maternal methyl donor supplementation produces offspring with different coat-colour, and different rates of obesity, diabetes and cancer. ${ }^{13}$ In addition, it is known that human identical twins do not show a 100\% correlation in terms of clinical expression of a specific condition.

Nevertheless, the notion that 'Orthotropics believes that teeth have the ability to align themselves if the face grows well' is a welcomed acknowledgement of the well-documented phenomenon of temporo-spatial patterning. ${ }^{14}$ In terms of challenging "the orthodontic profession to a debate to test the hypothesis that malocclusion is caused by the environment and modified by the genes', I fear that confrontation might be less productive than collaborative research. First, it might be agreed that the definition of malocclusion is outdated. ${ }^{12}$ Second, malocclusions, such as anterior open bite, vertical maxillary excess ('gummy smile'), posterior open bite and unilateral posterior open bite etc were not included in Angle's classification. Why not? It is likely that these outcomes were not commonly-observed at the time when Angle's classification was formulated. However, continued genetic variance has increased since then, as the effects of canalisation (buffering) have been modulated. In one study, ${ }^{15}$ we found that about $25 \%$ of children in a specific sub-population had an anterior open bite by the age of five years. To this end, working with an orthodontist, in a new publication entitled Epigenetic orthodontics in adults, ${ }^{16}$ I looked at both the theory of orthodontic tooth movement and the clinical outcomes 
in terms of facial, upper arch, lower arch and upper airway changes. Perhaps the most valuable insight is the notion that, despite canalisation, sutural homeostasis is the key to explaining both malocclusion and its clinical correction, with an enhanced level of craniofacial homeostasis.

G. D. Singh, Portland, OR

1. Mew M. A black swan? Br Dent J 2009; 206: 393.

2. Oppenheim A. Tissue changes, particularly of the bone, incident to tooth movement. American Orthodontist 1911; 3: 56-67.

3. Sandstedt C. Einige Beiträge zur Theorie der Zahnregulierung. Nordisk Tandläkare Tidskrift 1904; 5: 236-256.

4. Moss M L, Rankow R M. The role of the functional matrix in mandibular growth. Angle Orthod 1968. 38: 95-103

5. van der Klaauw C J. Cerebral skull and facial skull. Arch Neerl Zool 1946; 7: 16-37.

6. Moss M L. The functional matrix hypothesis revisited. 1. The role of mechanotransduction. Am J Orthod Dentofacial Orthop 1997: 112: 8-11.

7. Moss M L. The functional matrix hypothesis revis ited. 2. The role of an osseous connected cellular network. Am J Orthod Dentofacial Orthop 1997; 112: 221-226.

8. Moss M L. The functional matrix hypothesis revisited. 3. The genomic thesis. Am J Orthod Dentofacial Orthop 1997; 112: 338-342.

9. Moss M L. The functional matrix hypothesis revisited. 4. The epigenetic antithesis and the resolving synthesis. Am J Orthod Dentofacial Orthop 1997; 112: 410-417.

10. Singh G D. On growth and treatment: the Spatial Matrix hypothesis. In McNamara J A Jr (ed). Growth and treatment: a meeting of the minds. Craniofacial Growth Series vol. 41. pp 197-239. Ann Arbor, USA: Centre for Human Growth and Development, 2004.

11. Singh G D. Spatial matrix hypothesis. Br Dent 2007: 202: 238-239.

12. Singh G D. Outdated definition. Br Dent J 2007; 203: 174

13. Waterland R A, Jirtle R L. Transposable elements: targets for early nutritional effects on epigenetic gene regulation. Mol Cell Biol 2003; 23: 5293-5300.

14. Chaplain M A J, Singh G D, McLachlan J C (eds). On growth and form: spatio-temporal patterning in biology. John Wiley and Sons Publishers, 1999.

15. Lopez Del Valle L M, Singh G D, Feliciano N Machuca M Del C. Associations between a history of breast feeding, malocclusion and parafunctional habits in Puerto Rican children. $P$ R Health SciJ 2006: 25: 31-34

16. Singh G D, Krumholtz J A. Epigenetic orthodontics in adults. USA: Appliance Therapy Group, 2009 (in press).

DOI: 10.1038/sj.bdj.2009.614

\section{NEGATIVE BANNER}

Sir, am I the only one who cringes every time I see a piece of literature from the GDC that carries the header 'The General Dental Council - Protecting patients, regulating dentists'?

This must win the prize for the most negative PR ever foisted on the profession. Shouldn't a more appropriate and patient friendly line perhaps be 'The General Dental Council - Helping patients, supporting dentists'?
As it stands, patients naturally wonder why they need to be protected as a given from the healthcare professionals treating them in the vast majority of cases with holistic consideration and caring professionalism.

Most quality assurance studies will confirm that in all walks of life and occupations people strive to deliver the best they can with the processes on offer. Mistakenly considered no doubt a trendy by-line, this sort of stuff hardly helps, and very effectively becomes alienating and patronising.

Please let's spend some dosh on a good PR person to help the GDC get this right if they do not have sufficient imagination and creativity to do so inhouse and are obviously blind to its inherent message!

\section{K. Marshall}

By email

DOI: 10.1038/sj.bdj.2009.615

\section{GPS AND BISPHOSPHONATES}

Sir, I am writing to express my concern over the increasing number of our patients who are now receiving bisphosphonate medication from their general medical practitioners. On a commute to London recently I was in conversation with a GP and asked her what her opinion was on bisphosphonates, and following our discussion it prompted me to write in. To my shock she had no understanding of the implications to 'dentistry' that this medication has, and how it can interfere with minor oral surgery. Yet, in her own admission, she has seen an increase in her prescription of bisphosphonates. I understand this medication has positive effects for conditions, such as osteoporosis, but we dental practitioners are the ones faced with the complications that this drug provides. Surely, we need to voice this to our medical colleagues as it is they who are prescribing the medication, and from my own experience, patients who I have seen who take this medication have never been informed of the complications. It raises the question: should GPs be sending the patient for dental examination before prescription of oral bisphosphonates? DOI: 10.1038/sj.bdj.2009.616 